precipitate was filtered off and washed with methanol. Yield: 4.5 g (49\%). (Found: C 12.8; H 3.2; S 8.6; P 8.4; Ba 37.9. Calc. for $\mathrm{CH}_{3} \mathrm{CONHCH} \mathrm{CH}_{2} \mathrm{SPO}_{3} \mathrm{Ba}, 2 \mathrm{H}_{2} \mathrm{O}$

C 13.0; H 3.3; S 8.65; P 8.36; Ba 37.1).

1. Hansen, B. and Sörbo, B. Acta Radiol. 56 (1961) 141.

2. Åkerfeldt, S. Acta Radiol. 58 (1963) 465.

3. Åkerfeldt, S. Acta Chem. Scand. 17 (1963) 329.

4. Åkerfeldt, S. Acta Chem. Scand. 16 (1962) 1897.

5. Åkerfeldt, S. Acta Chem. Scand. 13 (1959) 1479 .

Received January 30, 1965.

\section{The Identity of Cyanein and Brefeldin A}

V. BETINA, ${ }^{a}$ P. NEMEC ${ }^{a}$ and Š. KOVAC̆ ${ }^{b}$

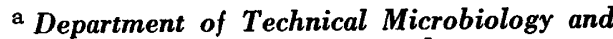
Biochemistry and

b Department of Organic Chemistry, Faculty of Chemistry, Slovak Technical University, Bratislava, Czechoslovakia

A. KJAER and R. H. SHAPIRO*

Department of Organic Chemistry, Royal Veterinary and Agricultural College, Copenhagen, Denmark

Cyanein is a crystalline antibiotic isolated $C_{\text {from Penicillium cyaneum }}{ }^{1}$ and possessing antifungal, ${ }^{1,2}$ anti-HeLa cell, ${ }^{3}$ and anti-nematodal ${ }^{4}$ activity. It also inhibits the growth of the root tips of Allium cepa ${ }^{5}$ and depresses the mitotic activity in the root tips of Vicia faba. ${ }^{6}$

Cyanein possesses the composition $\mathrm{C}_{16} \mathrm{H}_{24} \mathrm{O}_{4}$ (mol.wt. by mass spectrometry: 280 ) and its oxygen atoms were accounted

* Postdoctoral National Science Foundation Fellow, 1964-5. for by the presence of a lactone grouping and two secondary alcohol functions, which were readily acetylated to give a crystalline diacetate. On catalytic hydrogenation $(\mathrm{Pd} / \mathrm{C})$ cyanein afforded a crystalline tetrahydro-derivative. The NMR-spectrum (in $\left(\mathrm{CD}_{3}\right)_{2} \mathrm{SO}$ ) revealed the presence in cyanein of the grouping $\mathrm{CH}_{3} \mathrm{CH}(\mathrm{O}-)$, the system $-\mathrm{CH}=\mathrm{CH}-$ $\mathrm{CO}-\mathrm{O}$, as well as an isolated double bond. At this point of the structure work, Sigg ${ }^{7}$ published the structure of brefeldin A, an antibiotic produced by Penicillium brefeldianum, ${ }^{8}$ and identical with decumbin, ${ }^{9}$ previously isolated from Penicillium decumbens and preliminarily characterized as 'toxic to rats and to goldfish, and inhibitory to wheat germination, but not an active antibiotic under the tested conditions.' 10

On critical comparison of the published data $^{7}$ for brefeldin A, its diacetate, tetrahydro-derivative, and the diacetate of the latter, with those of the corresponding cyanein-derivatives, we can now conclude that cyanein is, in fact, identical with brefeldin A.

1. Betina, V., Nemec, P., Dobias, J. and Baráth, Z. Folia Microbiol. 7 (1962) 353.

2. Betina, V., Drobnica, Ľ., Nemec, P. and Zemanová, M. J. Antibiotics (Japan) Ser. $A 17$ (1964) 93.

3. Betina, V., Horáková, K. and Baráth, Z. Naturwiss. 49 (1962) 241.

4. Bačíková, D., Betina, V. and Nemec, P. Naturwiss. 51 (1964) 445.

5. Betina, V. and Nemec, P. Naturwiss. 50 (1963) 696.

6. Betina, V. and Murín, A. Cytologia (Tokyo). In press.

7. Sigg, H. P. Helv. Chim. Acta 47 (1964) 1401.

8. Härri, E., Loeffler, W., Sigg, H. P., Stähelin, H. and Tamm, C. Helv. Chim. Acta 46 (1963) 1235.

9. Singleton, V. L. and Bohonos, N. Agr. Biol. Chem. 28 (1964) 77.

10. Singleton, V. L., Bohonos, N. and Ullstrup, A. J. Nature 181 (1958) 1072.

Received January 29, 1965. 